\title{
Envisioning the Library's Role in Scholarly Communication in the Year $2025^{1}$ \\ Maria Carpenter, Jolie Graybill, Jerome Offord, Jr., and Mary Piorun
}

\begin{abstract}
This research probes future roles for libraries in the scholarly communication process through the use of scenarios. The researchers asked 20 ARL library directors to read and provide constructive comments on the scenarios, name the scenarios, and either select a scenario that most closely matched their vision or propose a new scenario. The directors identified six possible futures. Issues such as library as publisher, the economy, and the need for collaboration are discussed, as well as the timeframe for such futures and the desire versus the likelihood of a particular scenario happening.
\end{abstract}

\section{Introduction}

Scholarly communication is, in part, the process through which scholars and researchers communicate the results of research or other creative endeavors to their peers, formally or informally. ${ }^{1}$ Formal methods of scholarly communication include publication of books or articles in peer-reviewed journals, while informal methods, resulting in what is commonly referred to as grey literature, include publication of papers in conference proceedings, pre-prints, white papers, and posters. Grey literature is sometimes made publicly available on conference or personal Websites or is stored in institutional or subject repositories. Other methods of scholarly communication are the use of blogs, online discussions, social networking sites, "scholarly hubs" (Websites communities created to facilitate the connection and collaboration of researchers working within specific disciplines), the exchange of e-mails and phone calls, and face-to-face conversation. $^{2}$

The key players in scholarly communication are authors; editors of peer-reviewed journals and the peer-reviewers who make judgments about quality; publishers of peer-reviewed journals and scholarly books; various associations hosting subject repositories; database services

\footnotetext{
${ }^{1}$ This article first appeared in PORTAL: LIBRARIES AND THE ACADEMY, Volume 11, Issue 2, April, 2011, pages 659-681. Copyright $\odot 2011$ The Johns Hopkins University Press.
} 
and search engines that provide navigation, search, and retrieval functionality. The traditional role of libraries in the scholarly communication process has been to organize and provide access to physical and virtual collections, assist researchers and scholars in finding relevant sources and in locating citations to their works, and preserve the written works of their respective institution's scholarly community. ${ }^{3}$

Continuing developments in Web-based publishing software have had an impact on scholarly communication by (among other things) expanding the network of scholars and researchers sharing similar interests. Repositories (institutional and subject) and self-publishing technologies increase the availability of digital content that can be accessed from the office, home, or any location. The University of Rochester, for instance, added new features to its institutional repository to allow for version control of documents and allow faculty members to generate personal researcher pages similar to personal pages on Facebook. The goal of efforts such as these is to strengthen scholarly collaboration and to cultivate the use of institutional repositories. $^{4}$

Libraries are also attempting to alter the current scholarly communication process by promoting open access publishing alternatives. Educational programs have been developed to teach librarians how to talk to faculty about open access and address faculty concerns about peerreview and tenure. Open access initiatives are more important in some disciplines than others. Examples of such initiatives that have the potential to transform scholarly communication include the Directory of Open Access Journals (http://www.doaj.org/), the Scholarly Publishing and Academic Resources Coalition (SPARC, http://www.arl.org/sparc/), the National Institute of Health's (NIH) public access policy, institutional self-publishing projects such as York Digital 
Journals Project at York University, discipline-specific scholarly communication portals, and institutional repositories. ${ }^{5}$

With the evolution of open access initiatives, faculty involved in tenure and promotion processes have additional publishing venues to select when deciding where to publish. Tenure and promotion committees at local institutions continue to shape perceptions of quality and determine which research dissemination methods have greater authority within disciplines. While some institutional repositories and other digital publishing initiatives have flourished, overall acceptance by the majority of faculty involved in promotion and tenure has been lukewarm. Conversely, the consolidation of commercial publishers, the continued rise in cost of journals, and the impact of the global economic downturn on library budgets continue to challenge institutions and libraries to rethink, reuse, and repackage scholarly communication.

The role libraries assume in the future as they develop new services to meet the needs of faculty, researchers, and students is yet to be determined. The 2009 ITHAKA Survey describes the dilemma:

"On the one hand, the fields whose practices are most traditional appear to contain the library's greatest supporters; therefore, if the library shapes its roles and activities based on what is currently most highly appreciated by faculty, it may lose a valuable opportunity to innovate and position itself as relevant in the future. On the other hand, if the library develops new and innovative roles and services that address unmet needs, becoming newly relevant and even essential to those scholars who have moved furthest away from it, in the near term it may lose the support of its most ardent supporters."6

\section{Problem Statement}


In the increasingly complex world of scholarly communication and the varied technologies, tools, and services available to libraries - including institutional repositories, open access initiatives, self-publishing/e-publishing models, and social media software - librarians are in a position to envision, shape, and articulate their future role in scholarly communication. No study has systematically looked beyond the present and probed the role of libraries in the scholarly communication process for the near future. The purpose of this study is to fill that void by exploring different roles that libraries might assume. Those roles are cast in terms of future scenarios.

The findings of this study will benefit library managers as they reflect on the role of the library in the scholarly communication process and link that process to strategic planning, decision-making, and the accomplishment of the institutional mission. The study provides an opportunity for librarians to plan for change, either incremental or radical, and envision possible roles. By having a better idea of the role libraries could play in the future, library leaders can initiate strategic partnerships that prepare and position libraries to optimally serve the future needs of researchers in the area of scholarly communication. Moreover, librarians can work together with a broad set of stakeholders to ensure that their preferred visions, as identified through the research process, are achieved.

\section{Literature Review}

\section{Use of Scenarios}

Scenarios comprise mini case studies that lay out the components of a future direction and offer the experience of entertaining new and uncharted ideas when considering significant change. ${ }^{7}$ When organizations consider scenarios, the process provides opportunities for "informed conversations" by generating the broadest ideas of what a future could look like, 
depending upon different combinations of factors and forces. The ideas generated can then be applied by institutions considering a change in direction, improving short-term decision making and expanding long-term strategic planning. ${ }^{8}$

Scenarios have been developed to understand possible futures for digital libraries, ${ }^{9}$ the role of the Federal Depository Library Program in member libraries of the Association of Research Libraries (ARL) ${ }^{10}$ and the future of academic health science libraries. ${ }^{11}$ A current scenario project sponsored by ARL engaged the member community in contemplating possible situations in the future. The group pinpointed important implications and created a set of future scenarios. These scenarios were designed as a resource for member libraries to use in their strategic planning endeavors and to encourage organizational alignment focusing on change. Furthermore, a toolkit was developed for use by library leaders involved in planning and decision making. The intent was to identify the "social, technological, economic, political/regulatory, and environmental driving forces impacting research libraries in the future. $" 12$

In a recent study conducted by the Association of College and Research Libraries (ACRL), 26 future scenarios were identified. ${ }^{13}$ Five, of the scenarios in this particular futures study touched on the scholarly communication process and related issues. For example, one future included the opening and sharing of archival materials around the world while other futures cultivated open peer-review processes, online publications, and vigorous communitybased dialogue. Potential library roles in these futures included curating digital materials, promoting open access, partnering with commercial publishers regarding the use of textbooks and other materials for education and research, and greater cooperation with university presses.

\section{Future Role of Libraries in Scholarly Communication}


The literature on scholarly communication identifies a number of roles for libraries. One of these is to be a "nexus of communication," meaning that libraries are in a position to promote projects, assist users in discovering digital works, and fill an important need by addressing the issues associated with preservation of scholarship. ${ }^{14}$ Castelli states that the role of the library has traditionally been to provide metadata, promote standards, and to support open access initiatives. $^{15}$ To be successful in the new era of scholarly communication, however, librarians need to assume new roles. Lewis warns that libraries risk being overlooked if they fail to be proactive and do not present themselves as willing partners in initiating digital projects. ${ }^{16}$

One way that a library can become a nexus is to expand partnerships with faculty. Maron and Smith believe libraries can provide guidance on new projects by offering assistance with issues such as scholarly legitimacy and credibility. ${ }^{17}$ Many librarians recognize the need to take on additional responsibilities to support faculty in the research process, such as assistance with literature reviews. As service-oriented organizations, libraries need to forge stronger connections with users, incorporate user feedback, and design scholarly publishing systems that address user needs and information-seeking behavior. ${ }^{18}$ The Council on Library and Information Resources (CLIR) encourages libraries to take a leadership role in developing in-house training programs to prepare librarians to be an integral part of scholarly communication on their campuses. ${ }^{19}$ Librarians need to develop new abilities if they are going to play a proactive role in the future, including developing project management skills to aid in planning for long-term sustainability of new services, having a better understanding of the needs of faculty as authors, and developing better knowledge of the publishing process as a whole (e.g., selection, peer-review, and manuscript production)..$^{20}$ 
Another way for libraries to become central to the scholarly communication process is to move from being consumers to creators of information and to partner with local university presses. ${ }^{21}$ To achieve this shift, CLIR encourages libraries to become active in cross-campus collaborations for scholarly publishing, to manage institutional repositories and data curation projects, and to participate in the development of new digital resources. ${ }^{22}$ Writing on behalf of SPARC, Crow suggests that one future role for libraries is to partner with local university presses to create a new, stronger, and more viable publishing model. ${ }^{23}$ This kind of partnership may open up access to alternative sources of funding (government, philanthropic, or earned revenue), improve access to collections, and provide new publishing platforms.

Another way for libraries to become the nexus of scholarly communication is to help with information dissemination. One white paper on the university's role in the dissemination of research and scholarship recommends that institutions hold discussions on rights and management practices and on intellectual property policies. ${ }^{24}$ Additionally, libraries can help with dissemination by promoting the use of infrastructures such as institutional repositories and by expanding their capabilities. ${ }^{25}$

The National Institutes of Health (NIH) Public Access Policy, made permanent as part of the Omnibus Appropriations Act in March 2009, is considered a major step forward in scholarly communication and the role of the library in scholarly communication. Libraries used this opportunity to educate faculty, researchers, and administration about the larger open access (OA) movement and to assist with compliance issues. As Gedye declared, "If OA is to become the future of scholarly publishing, it needs skilled and responsible management, and librarians clearly possess the talents for this ... they may also become crusaders, educators, investors, aggregators, and developers, all with the ultimate goal of supporting an easily accessible, 
interconnected international network of quality research, available to all who might need to use it.",26

While both earlier and current research studies indicate early adoption of $\mathrm{OA}^{28},{ }^{27}$ The Calver and Bradley research, often considered an outlier, cites evidence of open access publishing stalling or not thriving as anticipated in the field of conservation studies. ${ }^{28}$ Calver and Bradley found that open access "had no statistically significant influence on the overall number of citations per journal paper. Journal papers were cited more frequently if the authors had published highly cited papers previously, were members of large teams of authors, or published relatively long papers, but papers were not cited more frequently if they were published in an OA source." 29 While this might not depict complete OA failure, Calver and Bradley's research shows that $\mathrm{OA}$ is not yet the thriving entity some proponents have chosen to illustrate.

\section{Objectives}

The objectives of this study are to develop a set of relevant scenarios that depict the role of the library in the scholarly communications process in 2025 , refine those scenarios, and develop titles for each scenario appropriately. As part of the study the researchers will then determine which scenarios generated the most interest.

\section{Procedures}

The literature review suggests three possible futures for the role of academic libraries in scholarly communication:

1. Status quo. Libraries continue to play an educational role in scholarly communication. Many libraries have a librarian tasked with educating faculty about scholarly communication issues and have representation on a faculty committee that deals with scholarly communication issues, such as journal pricing or open access mandates. Libraries invite faculty to participate in 
digital repositories, but the majority of faculty do not. The faculty tenure process remains unchanged, and faculty still want to be published by the most highly rated journals in the field, most of which are proprietary journals. Some open-access journals continue to thrive. Journal inflation continues its upward trend.

2. Increased support/leadership. Libraries increase their role in the arena of scholarly communication. Library leaders form committees and offices that work to develop new models of scholarly communication that support increased research efforts and access to information.

3. More of a central player. Through innovative partnerships, libraries become the "nexus" of scholarly communication. ${ }^{30}$ Libraries partner with faculty, publishers, and information technology specialists to push forward new models of scholarly communication that involve collaboration across campus and institutions. ${ }^{31}$

Based on these futures, the authors developed four initial scenarios, each of which projects a different plausible future role for libraries to assume in scholarly communication fifteen years into the future (i.e., 2025). When creating the initial scenarios, the authors took into account that looking beyond fifteen years lessens the accuracy of the prediction, ${ }^{32}$ and that a maximum of four scenarios is recommended when using this method. ${ }^{33}$ Each scenario should be plausible (depict a future that is capable of happening), differ from each other (together the scenarios offer different futures), have decision-making value (offer new understanding of the future that assists in planning and decision making), and be challenging (to conventional thinking about the future). This study aims to produce a final set of scenarios that meet the above criteria.

The initial set of scenarios identify four different roles for libraries, and assume additional changes in technology, collaboration, publishing models, the economy, and user behavior. In the first scenario, the status quo continues for the library as time passes and the 
majority of circumstances remain the same. In the second scenario, the library creates an office for scholarly communication. In the third scenario, the library showcases faculty and student research and collaboration is led by a scholarly communication team with various specialties. In the fourth scenario, the library becomes the publishing center on campus.

In writing these scenarios, the authors tried to avoid making assumptions for which there was no basis in the scholarly and research literature. Two experts on scholarly communication were selected to pre-test the scenarios. Based on their comments, the authors revised the introduction to the scenarios and incorporated feedback into the initial set of scenarios (see Appendix).

The researchers identified library directors to read and provide constructive comments on the scenarios. As is standard practice for this type of study, the authors compiled a purposive sampling frame of $\mathrm{X}$ elements with appropriate expertise and status, and the sample for the study $(n=20)$ may be characterized as a non-probability convenience sample at the element level drawn via the mechanism of self-selection (i.e., willingness to participate). ${ }^{34}$ Of the sample elements, fourteen are directors serving on one or more of three committees: the ARL Reshaping Scholarly Communication Strategic Direction Steering Committee, the Scholarly Publishing and Academic Resources Coalition's (SPARC) Steering Committee, or the Association of College and Research Libraries' (ACRL) Scholarly Communication Committee. These groups were chosen because they focus on leading a national agenda and strategic direction on scholarly communication on behalf of academic libraries. The remaining six directors were selected because of their former role in one of the aforementioned groups, specifically relating to scholarly communication activities. All of the participants were ARL library directors at the time of the research. 


\title{
Sample Frame of Directors
}

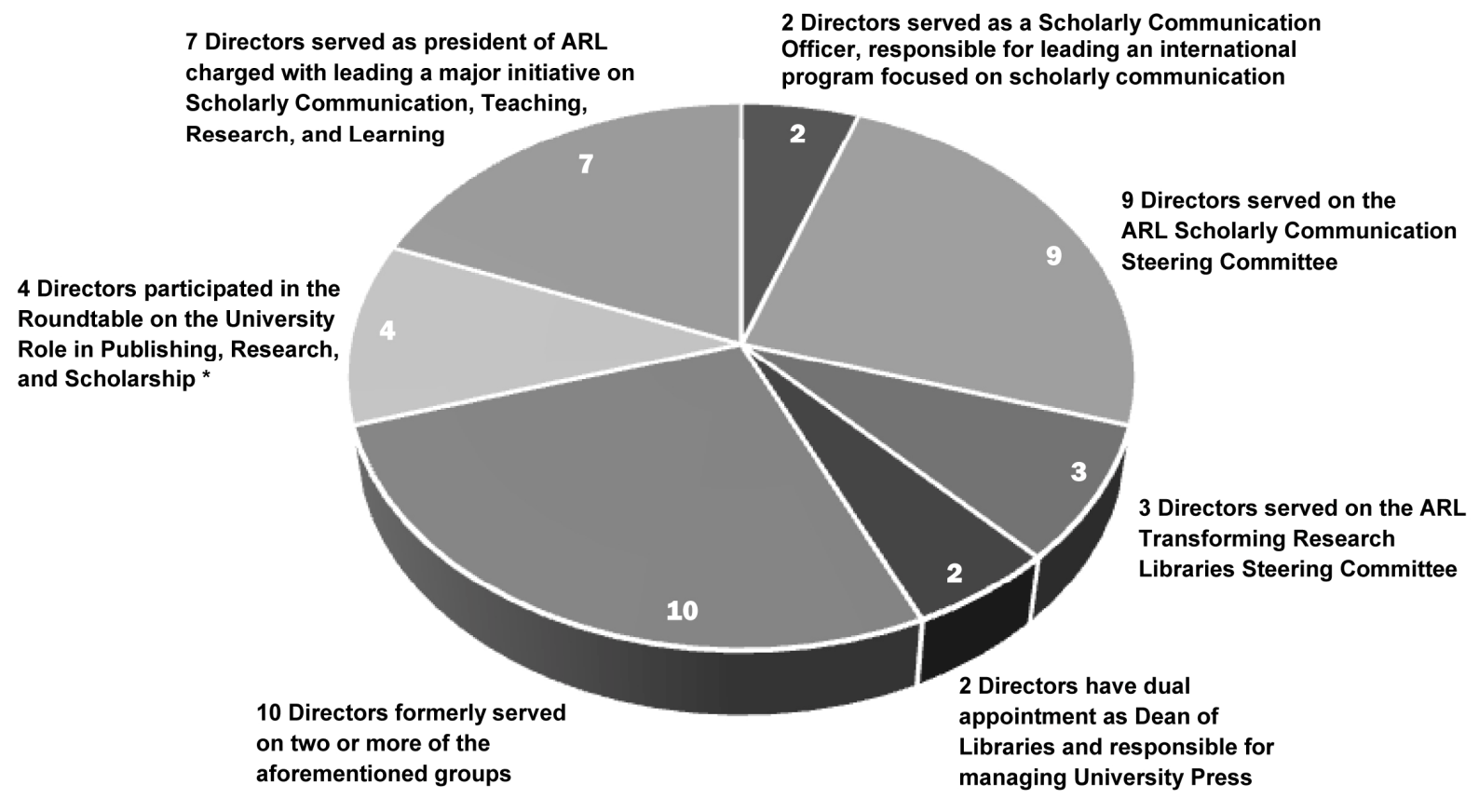

\begin{abstract}
* Sponsored by the Association of American Universities, the Association of Research Libraries, the Coalition for Networked Information, and the National Association of State Universities and Land Grant Colleges

** Some directors serve or have served on more than one committee at the same time
\end{abstract}

\section{Figure 1.}

\section{Findings}

Of the twenty ARL directors interviewed, in Phase One (see Figure 1) six directors, or 60.0 percent, selected one scenario, the remaining four, or 40.0 percent, chose a combination of two or more scenarios. Scenarios 3 (Librarians Role Reinvented) and 4 (Library as Publisher), either alone or in combination, were selected six times each. One participant in Phase One expanded scenario 4 and selected scenario $4 \mathrm{C}$ when asked which scenario was favored, bringing the total number of participants selecting scenario 4, or some element of scenario 4, to seven in Phase One. In addition, scenario 2 (Library as Catalyst) and scenario 3 (Librarians Role Reinvented) 
were selected three times in Phase One; scenario 2 was always selected in combination with another scenario. Scenario 5 (Failure to Succeed) was suggested as a possible future in Phase One but was not favored (see the Discussion section following Alternative Scenarios).

In Phase Two, similar to Phase One, five directors, or 50.0 percent, selected a single scenario and five selected a combination of two or more scenarios. Thus, 55.0 percent (11) of the directors chose one scenario. Scenario 3 (selected by six directors) was the favored scenario during this phase. Additionally, scenario 5 was selected in combination with scenarios 1-4 by one director, who stated that things are moving so quickly, and with the driving forces varying from library to library, the future is a combination of all the proposed scenarios. The sixth scenario (Alignment of Pedagogy with Practice) was suggested in Phase Two but was not selected.

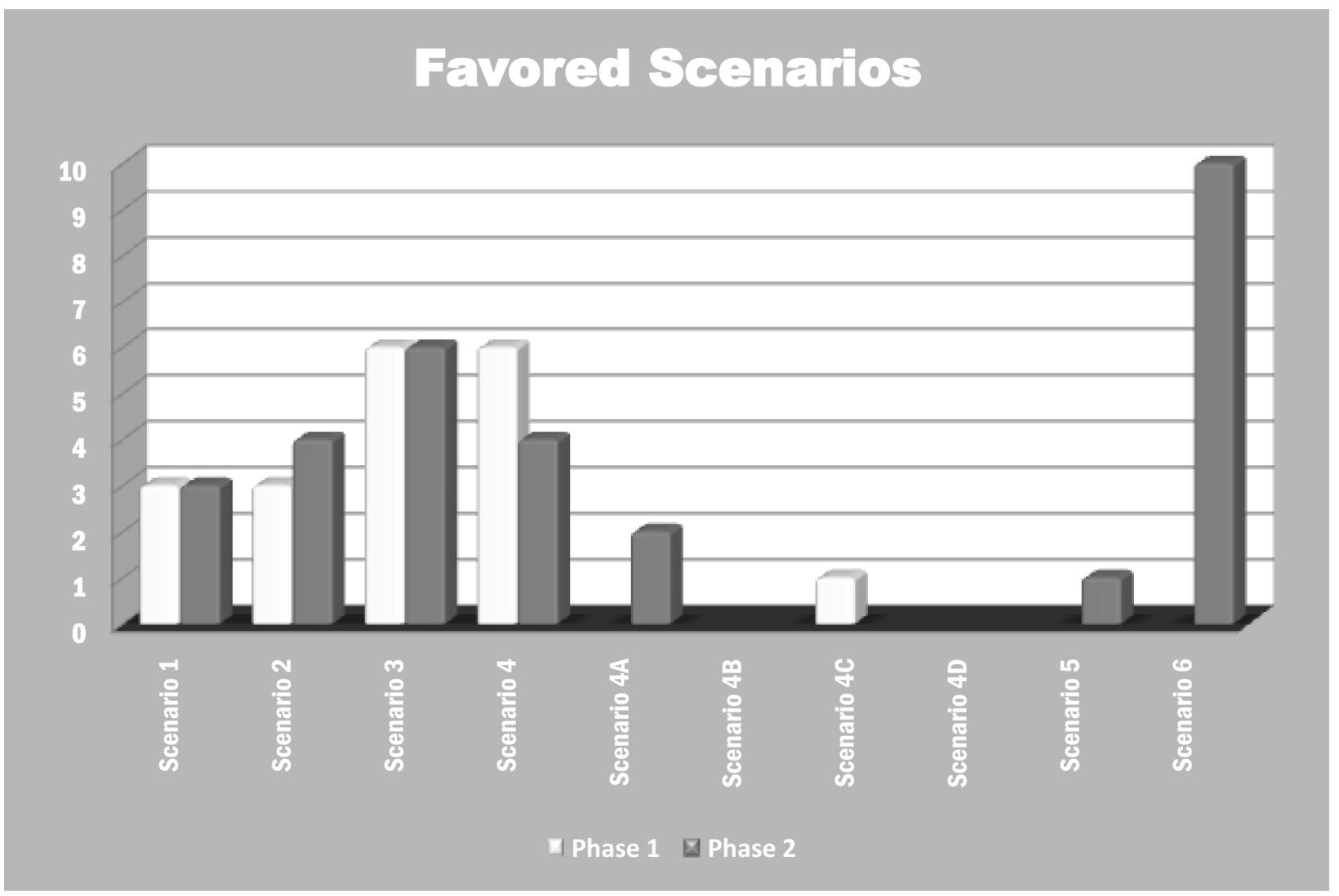

Figure 2. 
Although there were differences in the wording between Phase One and Phase Two scenarios, and while some directors preferred to select components from different scenarios, 13 of the directors, or 65.0 percent, preferred scenario 4 (Library as Publisher).

\section{Finalization of the Scenarios}

To highlight the changes in scenarios, the nonitalicized content in the following descriptions emphasizes results from the pretest and the Phase One of interviews which developed into five scenarios from the original four scenarios presented to the directors. The italicized content emerged during Phase Two of interviews with a final number of six scenarios.

\section{Scenario One (Surviving through Collaboration)}

Each year, the library faces additional cuts and difficult choices while trying to meet the research needs and requirements of faculty and students. The economic downturn of 2009 and 2010 and the subsequent slow recovery impacted the university's endowment, which has not regained its pre-recession performance. While faculty have been slow to embrace the principles of open access, the most recent mandate of Public Access for Federally Funded Research is proving impactful with a significant rise in deposits and faculty scrambling to identify new publishing opportunities. Credibility and reputation of discipline-specific open access journals are flourishing with increased submission of faculty articles.

The library increases its involvement in consortia partnerships in an attempt to share costs and provide access to needed databases and other resources. The consortial focus has shifted from like-type of library, such as research libraries, to public, private, academic and other types of libraries within a given region that work collaboratively to leverage each other's strengths and weaknesses. Decreasing budgets and increasing retirements forces the library to 
rethink staff expenditures and implement consolidation of some positions such as cataloging, with other like institutions. Sharing of resources expands, and the library begins to acquire institutional repository deposits from other institutions in the region.

The library continues to examine and evaluate resources in order to determine utilization, with efforts going to renegotiating contracts to eliminate pre-packaged collections that pair under-utilized resources with high demand items in an attempt to benefit from purchasing only requested items. Despite consequences of the three combined financial effects of shrinking budgets, recession, and journal inflation, the library persists in acquiring new materials, some of which include highly respected digital journals, and drop other less-utilized resources or items of diminished academic reputation. The library leads the local consortium in successfully cultivating a regional digital repository which showcases the research flow of participating institutions in a stunning display. Additionally, the library facilitates workshops and informational programs on open-access and scholarly publishing.

Driving forces for this scenario are university administrators, library directors addressing shrinking budgets, the impact of severe economic conditions, and expectations to expand formal collaborations with other institutions. The library increasingly is forced to do more with fewer resources while publishers and vendors continue to increase prices.

\section{Scenario Two (Library as Catalyst)}

The library takes an active role in scholarly communication and the protection of intellectual property on campus. The library, with support from the Provost, establishes an office of scholarly communication with the mission to increase access to scholarly works. The library is responsible for developing a long-term strategy with faculty, information technology services, and consortium members. The new strategy emerging from the collaboration allows librarians to 
actively promote scholarly communication across the institution and define their role in helping to protect the institution's intellectual property created by faculty. Faculty respond positively to the library's robust education program on author rights, and archiving of scholarly research and scientific data, regardless of the format, in the institutional repository. The library manages a fund to pay submission fees for faculty wanting to submit to open access journals. The office of scholarly communication collaborates and is recognized nationally in order to encourage faculty to incorporate scholarly communication issues into the curriculum and to engage students, especially graduate students. The office of scholarly communication partners with the office of sponsored research and faculty governance to adopt an open access mandate that reduces the transfer of copyrighted research, supports the rich tradition of publishing for tenure, and promotes global access to scholarship.

The driving forces for the creation of the scholarly communication office are the library's desire to: increase the university's role in dissemination of knowledge; help to aggressively shape author rights, such as retaining copyright on research and course materials used in an open curriculum forum; provide increased access to faculty research; and support an emerging scholarly communication model. The future of publishing is a growing cost for libraries and the condition of the economy is making it difficult for libraries to keep up with traditional print materials. The new scholarly communication models take into account retained copyright, open access, and varying digital formats included in the institutional repository. These new formats, along with the ways in which research is being disseminated, provide additional opportunities for faculty to publish scholarly research in many outlets, including making it available in institutional repositories and in the public domain. In this role, the library is fostering a deeper 
understanding of scholarly communication issues and building the university's institutional repository.

\section{Scenario Three (Librarians Role Reinvented)}

Collaboration flourishes between librarians, research faculty, and technology experts across the university. The library recruits staff with advanced subject knowledge, as well as expertise in data mining, management, and curation. These new skills, paired with expertise in information policy and copyright, result in a new type of library employee that bridges the gap between faculty needs and new library services. These new librarians are able to form vigorous, sustainable, long-term relationships with research faculty; they are recognized for their expertise and contributions and have become fully integrated into the department. Over the past decade, federally funded research was conducted to determine how faculty members work in specific disciplines and to discover how they used data. Subject librarians are able to apply

findings and collaborate fully with faculty on complex projects because they are viewed as partners in the research process. Librarians play a primary role in managing information for projects of all sizes, including bibliographic management, data creation and preservation, usagerights, and assisting with the distribution of finished works and raw data by promoting open access and local and national data repositories. The library continues to offer traditional curriculum-based support for teaching and learning. Librarians and library resources are embedded in each course, and when appropriate, librarians promote the use of raw data sets in the classroom. Archivists and preservation specialists apply their knowledge and skills to the digital environment.

The driving force is that the library leadership wants to provide relevant services for faculty and students in the new data intense environment. The library provides distinctive expert 
services (e.g. the creation of new tools for data mining), and relates these services with the university's desire to showcase, control, and highlight faculty output. As a result of funding agencies enforcing requirements for data plans that include how data will be shared and preserved for re-use, there is an identified gap (opportunity) to share best practices across the disciplines. The library director, being central, seizes his/her chance to coordinate activities by being a full partner at the start of projects. The library's primary roles include collaboration, information policy expertise, and data curation.

\section{Scenario Four (Library as Publisher)}

The library increasingly plays a role in scholarly publishing on campus and with the support of the academic leadership, takes on digital publishing operations as part of its primary operations, reallocating resources to this function. Four variations of this scenario are described below.

a. The library plays an important role in scholarly publishing on campus after taking time to learn how presses work and acquiring needed skills. Initially, the library manages the technology, then progresses to managing operations, and finally to leading the entire scholarly publishing enterprise. Publishing focuses on digital scholarship (away from book digitization that was in its heyday a decade ago). The library enfolds some of the former work of the university press, aggregators, and for-profit publishers into digital publishing operations and hires staff with expertise in marketing, document production, publishing, indexing, and editing to help with scholarly publishing efforts. As the role of publisher becomes a central function, the library reallocates resources, reinvents positions for digital publishing, and continues to attract supplementary funding for special related projects. The library provides all technology and expert support for 
digitizing and making globally available journals and digital products by faculty and departments. Additionally, the library provides a menu of services for potential authors to choose from, including peer-review management systems, collaboration platforms, and support for multimedia and data sets. The digital publishing program uses both open access and proprietary approaches and overlaps with the institutional repository and print on demand services. The library is fully enmeshed in the life cycle of scholarly publishing. The driving forces are the library and academic leaders intending to expand their role in the scholarly publishing process--shifting from providing access-- to creating and managing content, as well as the need for efficiencies of process in publishing. In essence, the library is redefining its role on campus as publisher and exploiting the opportunity to bring together an efficient way of handling scholarly publishing.

b. This version is similar to option a, but includes a successful open access model and university-wide policies established by administration to address governmental mandates in the humanities and sciences to make research more widely available to the public (historically begun with the NIH 2008 public access mandate). Under this model the university uses a template created by a library association, negotiated with any external publishers, and used at many other peer institutions, which gives institutions the right to retain a copy of every affiliated authors' works, whereas 15 years prior, each article needed to have an author rights amendment attached. Like scenario a, the library is fully enmeshed in the life-cycle of scholarly publishing and librarians have specific customized skills for each academic area. The driving force is the Federal government's mandates to provide research findings to the public and the library leadership's effectiveness at working with senior administration to come up with an enterprise-wide 
solution (policy) to operationalize open access and scholarly publishing of faculty research. In this version, similar to version a, the library is redefining its role on campus as publisher. Through this process, the library is beginning to define its role in research in new ways.

c. Publication in peer-reviewed journals continues to be the record for scholars in the academy and includes the best thinking and highest quality of production and review, as well as fine artwork and illustration. Working more closely with the affiliated University press, the library helps with related editorial development and production but does not publish official scholarship. Rather, the library helps to advance scholarly communication of faculty by making working papers, technical reports, pre- and -post white papers and grey literature internationally accessible. Although not as central to the core as version a, the library reallocates resources and reinvents positions for digital publishing and continues to attract supplementary funding for special related projects. The library provides technology and expert support for digitizing and making globally available the types of documents listed above by faculty and departments. The driving forces are the long-standing history and respect for peer-review and publication as it relates to tenure and promotion for faculty and the library's understanding and desire to support faculty and the academic mission, by working with university presses to further develop the scholarly publishing process. This is accomplished by seizing the opportunity to create, manage, and provide access to scholarly communication content that university presses were not providing.

d. Similar to a. but includes an organized global library and institutional effort supported by academic leaders worldwide. Participating higher educational institutions, scholars, 
and librarians will create this new global approach to scholarly publishing that ensures the highest quality peer-review. The driving forces are scholars' interest in global recognition, as well as library and academic leaders expanding their role in the scholarly publishing process. In this version, the library is redefining its role in scholarly communication on a global scale.

\section{Scenario Five (Failure to Succeed)}

Open access models are not sustainable and scholarly publishing does not advance. The majority of publishing is for-profit. The library budget is not able to match publisher price increases. The library faces tough negotiations in order to gain access to the information resources faculty, students, and researchers use daily in pursuit of teaching, learning, and research.

The driving force is faculty resistance to open access journals. Faculty fear the peerreview system will collapse, and the culture and long history of tenure being linked to publishing in high impact journals, causes faculty to work around the library. Faculty develop relationships with publishers based on their discipline to preserve the quality ensured by the peer-review process. These relationships are supported by both the institution and the publisher. Publisher consolidations have resulted in a few publishers holding all the power. Publishers form new alliances to develop the tools faculty need to speed-up the publication process; the library is not part of this process. The library is unsuccessful working with administrators or faculty to advocate for alternative publishing models.

\section{Scenario Six (Alignment of Pedagogy with Practice)}

The library collaborates with a local library science program in assuming a leadership role for teaching scholarly communication courses for graduate students. The course, taught by 
librarians currently working in academic libraries, is designed to give students the opportunity to investigate scholarly communication issues from a university perspective with Library Science theory and practice. The Institute of Museum and Library Services supports the new scholarly communication library program for Library Science research by providing funding for collaborative projects. Students are paired with tenured librarians in local academic libraries. Together, they are given the opportunity to work directly within identified subject areas to complete research projects, some that include collaborations with faculty in other fields, including submission for publication. Students are introduced to various scholarly publishing venues with opportunity for multiple submissions and presentations.

The driving forces in this scenario are leaders from both academic libraries and library science programs who collaborate to prepare students to be successful in this complex arena.

\section{Discussion}

Director comments from Phase One and Phase Two can be grouped into the following categories: multiple scenarios; alternative scenarios; the library's role in publishing; the economy as a driving force; the need for collaboration; not going far enough; desired futures versus likely futures versus aspirational futures; and complex environments.

\section{Multiple Scenarios}

Forty-five percent ( $\mathrm{n}=9$ ) (See Figure 2 above) of the directors chose a combination of two or more scenarios, indicating that no one scenario matched their future vision. Comments from these directors included the following statements: from Director 15, "The scenarios are not mutually exclusive of each other," and "Some percentage of these will happen, just a matter of how quickly," and from Director 13, "If I choose one then I am missing out." Director 1 read the sequence of scenarios presented as providing an increased response to the same problem. Some 
directors $[1,7-9,11-13,15$, and 16] commented that parts of each scenario might be applicable depending on size and type of library. In addition, participants expressed the opinion that libraries need to be involved in multiple areas in order to meet the needs of faculty, researchers, and students, all of whom are involved in scholarly communication issues to varying degrees. Director 15 pointed out that not every university has a press with which the library can partner, yet a library may still want to be involved in some type of publishing in the future as part of its scholarly communication program. With 13 of the directors selecting Scenario 4, this indicates that 65 percent of the directors interviewed see the library in 2025 as having a role in campus publishing. This is followed closely by 12 directors (60 percent) who selected scenario 3 , indicating that the future role for the library is forming strategic partnerships with faculty, researchers, and students and assisting with data management and preservation.

One of the strengths of scenario planning is the ability to generate multiple futures that can be used to facilitate discussion and debate. ${ }^{35}$ In addition to the 11 scenarios that came out of this study, the ACRL Futures Scenarios identified 26 other scenarios some of which contained aspects of scholarly communication, including print-on-demand, open access learning tools, distance education, continued publication in traditional peer-reviewed journals as the norm, and libraries not making headway in scholarly publishing and not being able to compete with information competitors. ${ }^{36}$ Choosing multiple scenarios may be reflective of uncertainty as to what the future brings in a rapidly changing environment or a desire to not miss out on any possibility.

\section{Alternative Scenarios}

The directors all believed the scenarios were relevant and that portions of them accurately 
portrayed the directions in which libraries were headed. However, six directors suggested additional scenarios.

\section{Creation of library as publisher that includes an open access model, Scenario $4 B$}

Director 10 affirmed strongly that open access was the only way to go and that university-wide policies continue to support governmental mandates. Several other Phase One directors did not believe this to be the case, so a separate version of scenario 4 that focused on open access to address governmental mandates was created (4B). As mentioned earlier, the NIH mandate provides libraries with an opportunity for further faculty engagement.

\section{Creation of library as publisher for non-official scholarship, Scenario 4C}

Director 8 suggested scenario (4C) because she did not believe that scholarly presses will disappear, unlike some of her peers: "publication is the record, the best thinking, and includes quality of production and review such as artwork and illustration." She acknowledged that researchers need help with editorial development and production but that the long-standing structure of peer review in scholarly publishing as it related to academe will not change. She hoped that libraries became involved in the management of scholarship. This director recognized that online scholars are having vigorous open dialogues about new ideas long before publication in peer-reviewed journals. Similarly, Director 6 maintained that even if libraries can publish scholarship operationally (and she believes they can), libraries will not be able to change the culture of how the journal system works to establish legitimacy within a discipline. "Publishing in prestigious, established journals is that which gives faculty credit toward tenure. Scholarly communication requires the established journals to proclaim this is quality." Director 6 also pointed to the concern that when aligning a library institution closer with a university press, the potential exists for perceptions to develop that the university press has turned into a vanity press, 
and thus may allow bias toward the university to develop. Scenario $4 \mathrm{C}$ was created based on comments such as those of Director 6 and Director 8 and to focus on publishing white papers, grey literature, dissertations, and technical papers (material that did not try to replace the types of materials required for tenure). This expanded role for academic libraries and their parent institutions is part of the transformation of scholarly publishing. ${ }^{37}$

\section{Creation of library as global publisher, Scenario $4 d$}

Director 14 thought that libraries' roles in publishing will be more collaborative and global in the future, believing that if libraries join forces, the possibility exists to change the infrastructure associated with publishing and still retain a robust peer-review system.

Globalization is mentioned in the Future Thinking for Higher Education Report: faculty come from all over the globe, universities will be online, and students select classes from various educational institutions. The scenario "library as a global publisher through collaboration" follows this global theme. As Director 14 and the ITHAKA Report point out strategic partnerships are critical -- this includes the library, university presses, and faculty working together to deliver new modes of publishing. ${ }^{38}$ This scenario ties the importance of collaboration to globalization through an organized approach.

\section{Creation of failure to succeed, Scenario 5}

Director 10 believed that it was possible that by 2025 open access could fail completely. Director 10 acknowledged that while this was not the current situation, given the input of other players (publishers and university faculty) the potential existed. This scenario was proposed in Phase One and shared with the directors in Phase Two. When asked about the scenario, Director 15 thought that this scenario described the present status, whereas Director 19 thought this future was unlikely, given the fact that numerous publishers already give faculty permission to post 
works in their home institutional repositories. Still, Director 14 could imagine such a future, stating that an entity besides the library steps in to provide the infrastructure needed for scholarly communication. All of the Phase Two directors commented on Scenario 5, indicating the seriousness of such a future and the issues it would raise for library directors. As is true of the scholarly community at large, the participants in this study shared mixed opinions about whether or not OA thrives.

\section{Alignment of pedagogy with practice, Scenario 6}

Director 19 from the Phase Two interviews, realizing that librarians need a new set of skills in order to be effective in advocating for changes in the scholarly communication process and assuming new roles, preferred library and information science programs to assume a leadership role in training future librarians in newly identified skills (data management, curation, and preservation, as well as greater knowledge of the publishing industry). He suggested an additional scenario (Alignment of Pedagogy with Practice) to address these needs. This requires libraries to work directly with library and information science deans to shape the curriculum and to prepare students to work in any of these scholarly communication scenarios. This need to develop new abilities is an opportunity to set the future of library schools to incorporate new curricula specifically designed to prepare librarians with well-honed scholarly communication skills in line with the publishing process, and "this may be a once in a century opportunity to

convince those in power that the field has a real contribution to make. ${ }^{, 39}{ }_{40}$

\section{The Library's Role in Publishing}

The participating directors, for the most part, consider that the library should participate in publishing but that there was a disparity of opinion of what that means and to what extent. In addition to the position that libraries should assist with related activities but not publish peer- 
reviewed journals, as noted in the Alternative Scenario section, two other roles envision publishing as becoming central to the library's work and providing infrastructure support.

\section{Central to the library's work}

Four of the directors $[4,5,9,12]$ were of the opinion that libraries should be in the business of scholarly publishing - two believed it should be central to the work of a university library [Director 5] and that support for the program should be built into the budget rather than being dependent on external funding [Director 4]. Director 15 stated that libraries have no knowledge of running presses and should stay away, pointing out that "libraries think publishing is easy; it is not. It must be sustainable and high quality. [Libraries] need a better understanding of what publishing is." Success comes with the ability to add "intellectual value on top of raw text." $40_{41}$ Providing this value is a new area for many ARL libraries; it may take time for library staff to acquire the necessary skills and be recognized as experts in this area.

\section{Provide infrastructure as a supporting partner}

Two directors [Directors 9 and 12] thought the library should be focused on publishing technology but not necessarily in a leading role: Director 9 stated "Libraries provide infrastructure but not intellectual leadership, ... [the] library has a role in technology, not necessarily leadership - it has to be case-by-case." Director 12 expressed the opinion that the focus of academic libraries should be on service. The focus on service and partnering with information technology leaders on campus was highlighted in a set of interviews conducted by Leigh Estabrook, who found that "They want a librarian with a service orientation who sees and understands the need to work with not only faculty and students but also with information technology specialists: someone who is effective in both collaboration and communication. ${ }^{, 41_{42}}$ 
Although there was no agreement on exactly what role the library assumes in publishing in the future, there was a strong sense among the majority of directors that the library has a role in suggesting new models, and coordinating experimentation with new technologies and formats. These roles were also suggested by Wittenberg. ${ }^{42^{43}}$

\section{Economy as Driving Force}

Several comments [Directors 2,4,7-9,13,15,18, and 20] were made about the economy as a driving force. The influence of the economy on scholarly communication was discussed throughout the interviews. Director 9 saw the economy as a "major force," adding that "current models of publishing are not affordable." Director 18 remarked that the 30 percent and 40 percent journal increases of the recent past are just that, a thing of the past; adding that the journal inflation rates for their campus had not even kept up with the most recent tuition increases.

Director 15 commented that there is always some sort of constraint and that journal inflation is an issue in both good and bad times. Echoing this sentiment, Director 4 noted that the economic recession is being used as a crutch and asserted that some libraries are so tied to traditional roles that the economic downturn has been used as the excuse for not adding new services. He felt that libraries "should take advantage of positive opportunities during an economic downturn to review traditional roles that might be holding the institution back from moving into emerging models of service."

There was an overall recognition that the health of the economy is taken into account when managing change and planning for the next stages of scholarly communication, but no clear answer as to what extent. As seen in the literature as well as participants comments, the 
economic downturn has triggered conversations nationally and library leaders are discussing the varying needs of libraries.

\section{Need for Collaboration}

The majority of directors [Directors 1-4,6,9,11-15, and 20] commented on the need for collaboration in each of the scenarios. Partners identified for potential collaboration include administration, faculty, students, researchers, associations, and library consortia. Libraries have to work in concert with these other players and as part of their parent institutions. Director 13, for instance, said "collaboration will be heightened in the next few years," and Director 14 pointed out "we must join forces." Both directors identified issues associated with collaboration, such as time, skill, and acceptance. When talking about scenario 3 (Librarians Role Reinvented), directors questioned whether or not librarians have the skills needed to be full partners in the research process. Director 6 said this is an opportunity to reemphasize the role of the librarian as having subject expertise and to de-emphasize the generalist trend. These directors view collaboration as a strategy for gaining buy-in and backing, cost-sharing and finding new opportunities for new revenue streams, engaging faculty, and affirming library expertise.

\section{Not Going Far Enough}

Fifty percent of directors commented that the future scenarios are too conservative [Directors 1,4-6,12,13, and 17] or not innovative enough [Directors 4,13, and 17], believing many of the issues raised to be addressed within five years or fewer [Directors 4,5, and 8]. Six directors [Directors 1,12-15, and 20] believed the scenarios described the current status and two described the scenarios as "retro" [Director 10] and "beyond" [Director 17], stating they described issues libraries already addressed. Director 6 observed that "[the scenarios] seem to be 
subtle changes around the edges rather than a major transformational shift." None of the directors, however, offered any radically different scenarios.

\section{Likely Futures Versus Desired Futures}

Director 8 pointed out that the future scenarios could be taken in two ways: likely possible futures or desired futures. She described these perspectives as "The future that may arise versus the future where libraries may want to live." The final scenarios were intended to capture possible futures that directors could envision. The tension between desired futures and perceptions of value is not unusual in "futures" studies. For example, the recent ACRL Futures Thinking for Academic Librarians: Higher Education in 2025 stated, “...Several ACRL leaders have indicated it is not enough to know the current state; we must also know what will be valued in the future and draw implications so that librarians can begin to take appropriate action

now." $43_{44}$ One research question addressed favored scenarios, however, as Director 8 highlighted, the study did not specifically probe the question of desired futures versus likely futures.

\section{Complex Environments}

Some directors [Directors $8,13,15,16$, and 17] also said that the scenarios did not capture the complexity of the environment in which libraries operate and the perspective of all those involved: university administration, faculty, students, and publishers. Multiple directors $[8,9,14,15,17]$ commented that the scenarios were very library-centric. As Director 8 put it, "scholarly communication is much larger than libraries, so it is quite difficult to talk about the role of the library in a vacuum." CLIR, and Brown, Griffiths, and Rascoff, and Thomas, have identified some of the leadership skills, emphasizing collaboration, needed so that libraries develop into active, equal team members in the ever complex scholarly communication field. ${ }^{44^{4}}$

\section{Limitations of the Study and Areas for Further Research}


The use of scenarios has a potential for lacking diverse input and viewpoints, confusion concerning roles, and possible inability to describe new and dynamic stories including strategic options; directors in the Complex Environments section above identified at least two of these components. Mietzner and Reger suggest it may be necessary to combine scenario planning with other future methods, such as Delphi or roadmapping techniques. ${ }^{45}$ The scenarios are grounded in a complex setting involving at least three different players: publishers, faculty authors, and library directors. Due to time, resources, and logistics, the authors only consulted one group -US-based ARL directors with significant documented experience in scholarly communication which may have resulted in futures that are not applicable to foreign libraries or libraries that have little experience in scholarly communications.

Future scenario studies might take into account the following: for-profit publishers; university faculty representatives from multiple disciplines; university administrators; information service professionals; and libraries of other types, sizes, regions (including international), and subject focus. Further exploration could include future scenarios with various scholarly communication cost models, including open access, and explore how these potential models affect the role of the library. And lastly, as suggested by one ARL director in Phase Two, further research could examine what graduate programs in library and information science are doing to prepare current students to participate in scholarly communication activities in the professional realm.

\section{Conclusion}

Library directors face challenges daily to approach library management issues from multiple perspectives for both today and the future. Future scenarios are used by leaders to explore different approaches for addressing the future, and "reorient our thinking., ${ }^{447}$ This research 
project asked research library directors to think about the potential challenges facing libraries and the future roles they will play in scholarly communication in higher education and at their local institutions. As a next step, library directors may want to focus on planning to achieve scenarios they desire or on preparing to handle specific scenarios or subsets of scenarios that may occur. The potential utility of the scenarios for individual libraries depends on the application of the possible, plausible, or aspirational futures question posited by one participant, while taking into consideration the local environment in which the library is set.

Changes in scholarly communication practices in research libraries are moving fast with all participants already actively engaged in defining the library's role in scholarly communication and believing it is a critical issue. While differences in opinion exist on how to address this issue, this study's findings indicate that the changing landscape of research, open access, data mining, and managing information and intellectual property rights has added urgency to the need to define the library's role in scholarly communication. A key factor that impacts the success of the changes in scholarly communication programs is collaboration; bringing diverse groups together was highlighted as an important skill for libraries that hope to have a role in future scholarly communication practices. The ITHAKA Report "found considerable interest in cross-institutional collaboration, and a feeling that some third party 'glue' is needed to make this happen." ${ }^{47}$ The necessity of collaboration came up in many of the interviews and all of the possible futures. It is critical that libraries continue to work within their institution along with stakeholders and with partner institutions to create a new scholarly communication structure and cultivate a prominent role in the new model. 
${ }^{1}$ Joan M. Reitz, Dictionary for Library and Information Science (Westport, CT: Libraries Unlimited, 2004).

${ }^{2}$ Nancy Maron, K. Kirby Smith, and ITHAKA, Current Models of Digital Scholarly

Communication (Washington, DC: Association of Research Libraries, 2008); Joan M. Reitz, Dictionary for Library and Information Science (Westport, Conn.: Libraries Unlimited, 2004); Mark Ware and Michael Mabe, The STM Report: An Overview of Scientific and Scholarly Journals Publishing (Oxford: International Association of Scientific, Technical and Medical Publishers, 2009).

${ }^{3}$ Mark Ware and Michael Mabe, The STM Report: An Overview of Scientific and Scholarly Journals Publishing (Oxford: International Association of Scientific, Technical and Medical Publishers, 2009).

${ }^{4}$ Steve Kolowich, "News: Encouraging Open Access" Inside Higher Ed http://www.insidehighered.com/layout/set/print/news/2010/03/02/repositories (accessed March $3,2010)$.

5 The NIH Public Access Policy implements Division F, Section 217, P.L. 111-8, which requires all investigators receiving funding from the NIH to submit (or have submitted for them) an electronic version of their final, peer-reviewed manuscripts. This submission to the National Library of Medicine's PubMed Central must occur no later than 12 months after the official date of publication.

${ }^{6}$ Roger C. Schonfeld and Ross Housewright, Faculty Survey 2009: Key Strategic Insights for Libraries, Publishers, and Societies, http://www.ithaka.org/ithaka-s-r/research/faculty-surveys2000-2009/Faculty\%20Study\%202009.pdf (accessed April 10, 2010). 
${ }^{7}$ Steve O'Connor and Lai-chong Au, "Steering a Future through Scenarios: Into the Academic Library of the Future," The Journal of Academic Librarianship 35, 1 (Elsevier, 2009).

${ }^{8}$ Logan Ludwig, Joan Giesecke, and Linda Walton, "Scenario Planning: A Tool for Academic Health Sciences Libraries," Health Information \& Libraries Journal 27, 1 (2010): 28-36.

${ }^{9}$ Marcos A. Gonçalves, Edward A. Fox, Layne T. Watson, and Neill A. Kipp, “Streams, Structures, Spaces, Scenarios, Societies (5S): A Formal Model for Digital Libraries," ACM Transactions on Information Systems 22, 2 (2004): 270-312; S. N. Vignesh, "The Future Scenario of Digital Library Era," SRELS Journal of Information Management 46, 1 (2009): 2528.

${ }^{10}$ Peter Hernon and Laura Saunders, “The Federal Depository Library Program in 2023: One Perspective on the Transition to the Future," College \& Research Libraries 70, 4 (2009): 351370.

${ }^{11}$ Ludwig, 28-36.

${ }^{12}$ Association of Research Libraries. Envisioning Research Library Futures: A Scenario Thinking Project, Association of Research Libraries, www.arl.org.library.unl.edu/rtl/plan/scenarios/index.shtml (accessed March/10, 2010).

${ }^{13}$ David J. Staley, Kara J. Malenfant, and Association of College and Research Libraries. Futures Thinking for Academic Librarians: Higher Education in 2025 (Chicago, IL: ACRL, Association of College \& Research Libraries, 2010).

${ }^{14}$ Nancy Maron, K. Kirby Smith, and Ithaka, Current Models of Digital Scholarly Communication (Washington, DC: Association of Research Libraries, 2008). 
${ }^{15}$ Donatella Castelli, "Digital Libraries of the Future — and the Role of Libraries," Library Hi Tech 24, 4 (2006): 496-503.

${ }^{16}$ David W. Lewis, "A Strategy for Academic Libraries in the First Quarter of the 21st Century" College \& Research Libraries 68, 5 (2007): 418-434.

${ }^{17}$ Nancy Maron, K. Kirby Smith, and ITHAKA, Current Models of Digital Scholarly Communication, (Washington, DC: Association of Research Libraries, 2008).

${ }^{18}$ Donatella Castelli, "Digital Libraries of the Future — and the Role of Libraries," Library Hi Tech 24, 4 (2006): 496-503; David W. Lewis, “A Strategy for Academic Libraries in the First Quarter of the 21st Century" College \& Research Libraries 68, 5 (2007): 418-434; Kate Wittenberg, "The Role of the Library in 21st-Century Scholarly Publishing" No Brief Candle: Reconceiving Research Libraries for the 21st Century (2008), http://www.clir.org/pubs/abstract/pub142abst.htm (accessed February 20, 2010).

${ }^{19}$ Council on Library and Information Resources, No Brief Candle: Reconceiving Research Libraries for the 21st Century: Council on Library and Information Resources, 2008, http:/www.clir.org/pubs/abstract/pub142abst.html (accessed February 20, 2010).

${ }^{20}$ Laura Brown, Rebecca Griffiths and Matthew Rascoff, "University Publishing in a Digital Age," ITHAKA. http://www.ithaka.org/ithaka-sr/strategy/Ithaka\%20University\%20Publishing\%20Report.pdf (accessed January/30, 2010); Sarah E. Thomas, "Publishing Solutions for Contemporary Scholars: The Library as Innovator and Partner," Library Hi Tech 24, 4 (2006): 563-573.

${ }^{21}$ Council on Library and Information Resources, No Brief Candle: Reconceiving Research Libraries for the 21st Century: Council on Library and Information Resources, 2008, http:/www.clir.org/pubs/abstract/pub142abst.html (accessed February 20, 2010); Raym Crow, 
"Campus-Based Publishing Partnerships: A Guide to the Critical Issues," Association of Research Libraries, http://www.arl.org/sparc/bm doc/pub_partnerships_v1.pdf (accessed February/20, 2010).

${ }^{22}$ CLIR, No Brief Candle.

${ }^{23}$ Crow, "Campus-Based Publishing Partnerships."

${ }^{24}$ Association of American Universities, Association of Research Libraries, The Coalition for Networked Information \& National Association of State Universities and Land Grant Colleges, "The University's Role in the Dissemination of Research and Scholarship -- a Call to Action," Association of Research Libraries, 2009 http//www.arl.org/bm doc/disseminating-researchfeb09.pdf (accessed March/5, 2010).

${ }^{25}$ Association of American Universities, et al., 2009 (accessed March/5, 2010).

${ }^{26}$ Richard Gedye, “Open access is only part of the story," Serials Review 30, 4 (2009): 271-4.

${ }^{27}$ Yassine Gargouri, Chawki Hajjem, Vincent Lariviare, Yves Gingras, Les Carr, Tim Brody, and Stevan Harnad, "Self-selected or mandated, open access increases citation impact for higher quality research," PLOS ONE 510 (2010): e13636; Steve Hitchcock, "The effect of open access and downloads ('hits') on citation impact: a bibliography of studies," (http://opcit.eprints.org/oacitation-biblio.html, 2010); Alma Swan, "The Open Access citation advantage: Studies and results to date," Technical Report, (School of Electronics \& Computer Science, University of Southampton, 2010). 
${ }^{28}$ Michael C. Calver, and J. Stuart Bradley, "Patterns of Citations of Open Access and Non-open Access Conservation Biology Journal Papers and Book Chapters," Conservation Biology 24, 3 (Blackwell Publishing Inc., 2010): 872-880.

${ }^{29}$ Ibid.

${ }^{30}$ Nancy Maron, K. Kirby Smith, and ITHAKA, Current Models of Digital Scholarly Communication, (Washington, DC: Association of Research Libraries, 2008).

${ }^{31}$ Kate Wittenberg, "The Role of the Library in 21st-Century Scholarly Publishing," No Brief Candle: Reconceiving Research Libraries for the 21st Century (2008), http://www.clir.org/pubs/abstract/pub142abst.htm (accessed February 20, 2010).

${ }^{32}$ Joseph P. Martino, "The Precision of Delphi Estimates," Technological Forecasting, 1, 3 (1970): 293-299.

${ }^{33}$ Dana Mietzner and Guido Reger, "Advantages and Disadvantages of Scenario Approaches for Strategic Forecasting," International Journal of Technology Intelligence and Planning 1, 2 (2005): 220-239.

${ }^{34}$ Ronald R. Powel and Lynn Silipigni Connaway, Basic research methods for librarians (Library and information science text series, 4th ed., Westport, CT Libraries Unlimited, 2004).

${ }^{35}$ Mietzner, "Advantages and Disadvantages of Scenario Approaches."

${ }^{36}$ David J. Staley, Kara J. Malenfant, and Association of College and Research Libraries. Futures Thinking for Academic Librarians: Higher Education in 2025 (Chicago, IL: ACRL, Association of College \& Research Libraries, 2010). 
${ }^{37}$ Laura Brown, Rebecca Griffiths and Matthew Rascoff, "University Publishing in a Digital Age," ITHAKA. http://www.ithaka.org/ithaka-s-

r/strategy/Ithaka\%20University\%20Publishing\%20Report.pdf (accessed January/30, 2010): 3.

${ }^{38}$ Ibid, 29.

39 Andrew Dillon and April Norris, "Crying wolf: An examination and reconsideration of the perception of crisis in LIS education," Journal of Education for Library and Information Science 46, 4 Fall (2005): 280-298.

${ }^{40}$ CLIR, No Brief Candle, 6.

${ }^{41}$ Leigh Estabrook and Association of College and Research Libraries, "What Chief Academic Officers Want from Their Libraries: Findings from interviews with Provosts and Chief Academic Officers (Chicago, IL: ACRL, Association of College \& Research Libraries Presidents Program, 2006)

${ }^{42}$ CLIR, No Brief Candle, 39-40.

${ }^{43}$ Staley, Futures Thinking for Academic Librarians.

${ }^{44}$ CLIR, No Brief Candle; Brown, "University Publishing in a Digital Age."

${ }^{45}$ Mietzner, “Advantages and Disadvantages of Scenario Approaches.”

${ }^{46}$ Staley, Futures Thinking for Academic Librarians, 23.

${ }^{47}$ Brown, "University Publishing in a Digital Age," 7. 


\section{Authors Contact Information}

Maria Carpenter

Director, Advancement, Marketing \& Communications

University Libraries

Northeastern University

360 Huntington Ave.

Boston, MA 02115

m.carpenter@neu.edu, 617.373.5409 (Fax), 617.373.2821 (Phone)

Jolie Graybill

Image \& Mulitmedia Collections Coordinator

University of Nebraska-Lincoln Libraries

13th and R Streets

Lincoln, NE 68588

Jgraybill3@unl.edu, 402.472.5181 (Fax), 402.472.4547 (Phone)

Jerome Offord, Jr.

University Librarian and Head, Department of Library Science

Inman E. Page Library

Lincoln University

712 Lee Drive

Jefferson City, MO 65101

offordj@lincolnu.edu, 573.681.5511 (Fax), 573.681.5501 (Phone)

Mary Piorun

Associate Director, Lamar Soutter Library

University of Massachusetts Medical School

55 Lake Ave. North

Worcester, MA 01655

Mary.piorun@umassmed.edu, 508.856.5039 (Fax), 508.856.5039 (Phone) 